\title{
Isolation of Viruses from Wild Japanese Flounder Paralichthys olivaceus
}

\author{
Ryoko Takano ${ }^{1 *}$, Koh-ichiro Mori², Toyohiko Nishizawa' ${ }^{1}$, Misao Arimoto ${ }^{2}$ \\ and Kiyokuni Muroga ${ }^{1}$ \\ ${ }^{1}$ Faculty of Applied Biological Science, Hiroshima University, Higashi-hiroshima 739-8528, Japan \\ ${ }^{2}$ Kamiura Station of Japan Sea-Farming Association, Kamiura, Oita 879-2602, Japan
}

(Received March 8, 2001)

\begin{abstract}
For a survey on fish pathogenic viruses among wild Japanese flounder Paralichthys olivaceus, 274 fish (body weight: 29-2240 g) were collected in 9 coastal areas of Japan in 1999 and 2000. Aquabirnaviruses were isolated, using RTG-2 and/or SSN-1 cells, from 111 fish (40.5\%) caught in almost all the coastal areas and the representative isolate was identified as YTAV (yellowtail ascites virus) by cross-neutralization tests. Besides aquabirnaviruses, VHSV (viral hemorrhagic septicemia virus) was isolated, using EPC, SSN-1 and/or FHM cells, from 18 fish (6.6\%) collected in 2 areas mainly in winter and spring. In a pathogenicity test, 4 isolates of aquabirnaviruses did not cause any mortality or morbidity in young Japanese flounder (average body weight $8.7 \mathrm{~g}$ ) by intramuscular injection at $10^{3.0}-10^{7.6} \mathrm{TCID}_{50} /$ fish. Inoculation of an isolate of VHSV at $10^{2.0}$ and $10^{6.0} \mathrm{TCID}_{50}$ /fish produced mortalities of $60 \%$ and $100 \%$, respectively, in flounder $(24.8 \mathrm{~g})$. Common external signs of flounder experimentally infected with VHSV were dark coloration of the body with hemorrhagic fins and abdominal swelling, and the internal signs included ascites and extensive hemorrhage in the muscle and/or viscera.
\end{abstract}

Key words: aquabirnavirus, VHSV, YTAV, Paralichthys olivaceus, virus isolation, wild fish, Japanese flounder

For the improvement and development of coastal fisheries stocks, the Japanese government has supported hatchery-based marine stock enhancement programs. For that purpose, about 40 marine fin-fish species are annually produced in national and prefectural hatcheries. In addition, juveniles of several fish species are produced in private hatcheries as seed for aquaculture.

Seed production techniques for major fish species have been well developed, however, difficulties in controlling diseases caused by infectious agents, especially by viruses, are often encountered during seed production (Muroga, 1995, 2001). For example, birnavirus infection caused by yellowtail ascites virus, YTAV (= YAV, Leong et al., 2000) in yellowtail Seriola quinqueradiata (Sorimachi and Hara, 1985) and Japanese flounder Paralichthys olivaceus (Kusuda et al., 1989), and viral nervous necrosis (VNN) by nodavirus in striped jack Pseudocaranx dentex (Muroga et al., 1998)

* Corresponding author

E-mail: maruko@hiroshima-u.ac.jp have been reported. It has been shown that some of these agents originate from wild adult fish captured as a brood stock in marine environment (Mushiake et al., 1994; Muroga, 2000). In addition to this problem caused by vertical transmission of the pathogen during seed production, there is another problem that we must take into consideration: that is mortalities of released fish due to infectious agents in the marine environment. Therefore, investigations on the distribution of pathogenic viruses in wild populations of fish are very important. However, to date, such surveys have not been conducted in the coastal area of Japan except for a few reports (Isshiki et al., 1989).

In the seed production and secondary nursery stages of Japanese flounder, some viral diseases have been reported; YTAV infection (Kusuda et al., 1989), VNN (Nguyen et al., 1994) and viral epidermal hyperplasia caused by a herpesvirus (lida et al., 1989). In growout stages of flounder, hirame rhabdovirus (HIRRV) infections (Kimura et al., 1986), red sea bream iridovirus (RSIV) infections (Matsuoka et al., 1996) and lymphocystis disease (Tanaka et al., 1984) have been reported. 
In addition, since 1996, severe anemia has been observed in both wild and cultured Japanese flounder. Miwa and Inouye (1999) observed virus-like particles in cells of the hematopoietic tissue of the anemic fish, although the role of the virus remained unsolved, thus virological studies on this disease were required.

Under these circumstances, we have conducted a survey on the prevalence of fish pathogenic viruses among wild Japanese flounder caught in various coastal areas of Japan.

\section{Materials and Methods}

\section{Sampling}

Wild Japanese flounder for virus isolation were caught in 9 coastal areas of Japan in 1999 and 2000 as shown in Fig. 1 and Table 1. In the present study, fish, which were judged to be released fish from their abnormal pigmentations on blind sides, were omitted from the samples. Most of the fish were collected by using gill net (Sashiami) and immediately transferred in individual plastic bags in live state to the Kamiura Station of Japan Sea-Farming Association (JASFA). Hematocrit value $(\mathrm{Ht})$ was measured for the determination of anemic condition of fish before processing the samples. Total number of fish examined in this study was 112 fish (body weight: 29-1,088 g, average: $435 \mathrm{~g}$ ) in 1999 and 162 fish (body weight: 73-2,240 g, average: $717 \mathrm{~g}$ ) in 2000 (Table 1). Tissues of the head kidney and brain were removed from individual fish and stored at $-80^{\circ} \mathrm{C}$ until further processing.

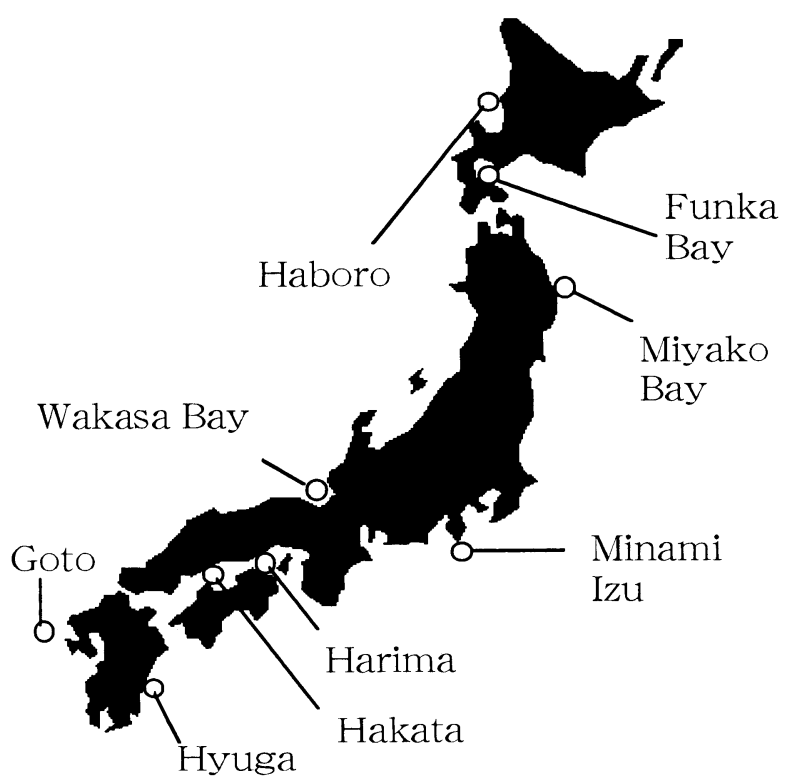

Fig. 1. Locations of the sampling sites of Japanese flounder for virus isolation.

\section{Virus isolation}

Virus isolation was conducted by inoculating filtered ( $0.45 \mu \mathrm{m}$ membrane filter) homogenates of the tissues prepared with 9 volumes of Hanks' balanced salt solution (HBSS) onto 3 established fish cell lines, RTG-2, EPC and SSN-1 (from striped snakehead, Frerichs et al., 1996, provided by Dr. M. Yoshimizu). In 2000, FHM cell line was also used in addition to these 3 cell lines because of its high susceptibility to VHSV (viral hemorrhagic septicemia virus) isolates from flounder. When samples were inoculated to FHM cells, sample homogenates were mixed with an anti-YTAV serum to enhance the isolation of non-aquabirnaviruses. These cell lines were maintained using Leibovits L-15 (Gibco) for SSN-1 or Eagle's MEM (Nissui) for the others supplemented with $10 \%(\mathrm{~V} / \mathrm{V})$ fetal bovine serum, $150 \mathrm{lU} / \mathrm{mL}$ penicillin $\mathrm{G}$ and $50 \mu \mathrm{g} / \mathrm{mL}$ kanamycin sulfate. Each cell line was cultured for 1 day in 24-well plate before inoculated with the sample filtrates ( 2 wells per sample). Inoculated cells were incubated at $20^{\circ} \mathrm{C}$ for 14 days. The supernatant of cells showing cytopathic effect (CPE) was sub-cultured onto the same cell line and observed for another 14 days.

\section{Virus neutralization test}

The difference in CPEs observed in inoculated cells indicated that 2 types of viruses were isolated from flounder, and based on electron microscopic observation of the particles, they were suspected to be a rhabdovirus and a birnavirus. Then cross-neutralization tests were performed among rhabdoviruses (IHNV, HIRRV and the present rhabdovirus-like isolates, Obama \#25 and \#26) and among birnaviruses (IPNV serotypes VR-299, Ab and $\mathrm{Sp}$ and YTAVs: isolates from yellowtail and Japanese flounder, and the present birnavirus-like isolate, Obama \#10), using antisera to the respective viruses. Two-fold serial dilutions of each antiserum were mixed with an equal volume of a viral suspension containing approximately $10^{2.0} \mathrm{TCID}_{50} / 50 \mu \mathrm{L}$ and incubated at room temperature $\left(20-23^{\circ} \mathrm{C}\right)$ for $1 \mathrm{~h}$. Aliquots of each mixture (100 $\mu \mathrm{L} /$ well) were transferred to 2 wells of 96 -well microtitre plates seeded with cells (FHM cells for rhabdoviruses and RTG-2 cells for birnaviruses), and neutralizing titre was determined after 14 day-incubation at $20^{\circ} \mathrm{C}$.

To identify the remaining isolates showing CPE typical to aquabirnavirus, they were submitted to a qualitative neutralization test using an antiserum against the new isolate Obama \#10. Briefly, 10-fold serially diluted viral suspensions of each isolate were mixed with an equal volume of the antiserum diluted at $10^{-3}$ or with HBSS (control) and incubated for $1 \mathrm{~h}$ at room temperature. Then $100 \mu \mathrm{L}$ of each mixture was inoculated onto RTG- 2 cells cultured in 96-well microtitre plates ( 2 wells for each dilution). Inoculated cells were incubated at $20^{\circ} \mathrm{C}$ for 14 days and the sample which showed the 
Table 1. The results of virus isolation from Japanese flounder caught in various areas in 1999 and 2000

\begin{tabular}{|c|c|c|c|c|}
\hline \multicolumn{2}{|c|}{ Sampling } & \multirow{2}{*}{$\begin{array}{l}\text { Number of fish } \\
\text { examined }\end{array}$} & \multicolumn{2}{|c|}{ Number of fish positive for } \\
\hline Location & Season*1 & & VHSV & Aquabirnavirus \\
\hline \multicolumn{5}{|l|}{ (1999) } \\
\hline Haboro & Autumn & $18\left(0^{* 2}\right)$ & 0 & $5(0)$ \\
\hline Funka Bay & Winter & $5^{* 3}(0)$ & 0 & 0 \\
\hline Miyako Bay & Autumn & $18(2)$ & 0 & $8(1)$ \\
\hline \multirow{3}{*}{ Wakasa Bay } & Winter & $11(8)$ & $2 * 5(1)$ & $8(6)$ \\
\hline & Spring & $5^{* 4}(4)$ & 0 & $5(4)$ \\
\hline & Autumn & $18(1)$ & 0 & $4(0)$ \\
\hline \multirow{2}{*}{ Minami Izu } & Spring & $10^{\star 4}(8)$ & 0 & $10(8)$ \\
\hline & Summer & $11(6)$ & 0 & $6(2)$ \\
\hline \multirow{2}{*}{ Hakata Island } & Winter & $4(3)$ & 0 & $4(3)$ \\
\hline & Autumn & $1(0)$ & 0 & 0 \\
\hline Harima & Spring & $11(7)$ & 0 & $1(1)$ \\
\hline Subtotal & & $112(39)$ & $2(1)$ & $51(25)$ \\
\hline \multicolumn{5}{|l|}{ (2000) } \\
\hline \multirow{4}{*}{ Miyako Bay } & Winter & $4(2)$ & 0 & $4(2)$ \\
\hline & Spring & $2(2)$ & 0 & 0 \\
\hline & Summer & $5(3)$ & 0 & 0 \\
\hline & Autumn & $8(5)$ & 0 & $2(1)$ \\
\hline \multirow{4}{*}{ Wakasa Bay } & Winter & $9(6)$ & 0 & $9(6)$ \\
\hline & Spring & $23(10)$ & $2(1)$ & $8(5)$ \\
\hline & Summer & $19(5)$ & 0 & $7(1)$ \\
\hline & Autumn & $6(2)$ & 0 & $2(1)$ \\
\hline \multirow{2}{*}{ Minami Izu } & Winter & $9(2)$ & 0 & $5(0)$ \\
\hline & Spring & $6(1)$ & 0 & $5(1)$ \\
\hline \multirow{4}{*}{ Hakata Island } & Winter & $13(0)$ & 0 & 0 \\
\hline & Spring & $26(2)$ & $10^{* 6}(1)$ & $9(1)$ \\
\hline & Summer & $7(2)$ & $4(1)$ & 0 \\
\hline & Autumn & $5(2)$ & 0 & $1(1)$ \\
\hline Hyuga & Winter & $10(6)$ & 0 & $6(3)$ \\
\hline Goto & Winter & $10(0)$ & 0 & $2^{* 7}(0)$ \\
\hline Subtotal & & $162(50)$ & $16(3)$ & $60(22)$ \\
\hline Total (\%) & & 274 & $18(6.6 \%)$ & $111(40.5 \%)$ \\
\hline Anemic fish & & 89 & $4(4.5 \%)$ & $47(52.8 \%)$ \\
\hline Healthy fish & & 185 & $14(7.6 \%)$ & $64(35.1 \%)$ \\
\hline
\end{tabular}

*1: Spring: March to May, Summer: June to August, Autumn: September to November, Winter: December to February.

*2. Number of anemic fish is given in a parenthesis (hematocrit value was $<20$ ).

$* 3 * 4$ : Tissues of the brain and head kidney were separately submitted to the virus isolation except some samples where only brain $\left({ }^{* 3}\right)$ or head kidney $\left({ }^{* 4}\right)$ were submitted.

*5: Coinfected with aquabirnavirus.

*6: Five out of 10 samples were coinfected with aquabirnavirus.

${ }^{* 7}$ : Unclassified virus was isolated from one aquabirnavirus-positive sample.

reduction of virus titre $\left(\geqq 10^{1.0} \mathrm{TCID}_{50}\right)$ were determined as aquabirnavirus-positive.

Indirect immuno-fluorescent antibody technique (IFAT)

The two isolates, Obama \#25 and \#26 from flounder caught in Wakasa Bay in 1999, were identified as VHSV as already reported in the previous paper (Takano et al., 2000). In the present study, the remaining isolates of rhabdovirus cultured in FHM cells were verified as VHSV by immuno-fluorescence as described by Olesen and Lorenzen (1999). A monoclonal antibody (MAb) against VHSV N protein (IP5B11; Lorenzen et al., 1988) 
provided by Dr. N. J. Olesen (Danish Veterinary Laboratory) was applied as the primary antibody at a dilution of 1 : 100 and a FITC-conjugated rabbit antiserum to mouse Ig (1:40, DAKO) was applied as the secondary antibody.

\section{Electron microscopy}

Supernatant of cultured SSN-1 cells infected with the aquabirnavirus isolate Obama \#10 was harvested when all the cells were detached from the bottom of the flask. The virus solution was centrifuged at $10,000 \times g$ for $20 \mathrm{~min}$ to remove the cell debris and again centrifuged at $150,000 \times g$ for $90 \mathrm{~min}$. Virion pellet was suspended in phosphate-buffered saline (PBS) containing $\mathrm{CsCl}$ (specific gravity 1.32), followed by centrifugation at $150,000 \times g$ over night, and a visible virus band was collected. The virus sample was placed on carboncoated grids and negatively stained with $2 \%$ phosphotungstic acid ( $\mathrm{pH} 7.8)$.

\section{Pathogenicity test of the isolated virus}

Aquabirnavirus: Four isolates of aquabirnavirus, Obama \#10, Obama \#29, Izu \#6 and Izu \#20, were used in this test. Obama \#10 and Izu \#20 were isolated from apparently healthy Japanese flounder, while Obama \#29 and Izu \#6 were from anemic flounder ( $\mathrm{Ht}$ were 18 and 10 , respectively). Viruses were stored after 3 or 4 passages on RTG-2 cells and titrated. Healthy Japanese flounder (average body length $9.7 \mathrm{~cm}$, body weight 8.7 g) reared at the Kamiura Station of JASFA were used. Two concentrations of each isolate were prepared (Obama \#10, $10^{3.0}$ and $10^{3.9}$, Obama \#29, $10^{3.0}$ and $10^{6.6}$, Izu \#6, $10^{3.0}$ and $10^{5.9}$, Izu \#20, $10^{3.0}$ and $10^{7.6} \mathrm{TCID}_{50}$ / fish) and injected intramuscularly (i.m.) at $100 \mu \mathrm{L} /$ fish to 15 fish kept in a $100 \mathrm{~L}$ tank. In a control group, 15 fish were injected with MEM medium supplemented with $10 \%$ FBS (MEM10). Water temperature was maintained at $20^{\circ} \mathrm{C}$ and fish were monitored for 20 days.

VHSV: Obama \#25 isolate from an apparently healthy flounder was used as an inoculum. Virus was stored following 3 passages and titrated using FHM cells. Healthy Japanese flounder $(13.8 \mathrm{~cm}, 24.8 \mathrm{~g})$ reared at the Kamiura Station were challenged by i.m. injection. Prior to injection, fish were acclimatized to a laboratory condition at $13^{\circ} \mathrm{C}$ for 4 days and then randomly sampled 10 fish were sacrificed to confirm the absence of aquavirnavirus and VHSV by isolation. Two doses of the virus preparations, $10^{6.0} \mathrm{TCID}_{50} /$ fish (high dose) and $10^{2.0} \mathrm{TCID}_{50} /$ fish (low dose), or MEM10 (control) were injected to each 10 fish reared in a $100 \mathrm{~L}$ tank. Fish mortalities were monitored daily for 11 days post inoculation. Water temperature was maintained at $13^{\circ} \mathrm{C}$ throughout the experiment. $\mathrm{TCID}_{50}$ titration of the virus from the moribund fish and survivors (brain, head kidney and heart) was performed using FHM cells.

\section{Results}

\section{Virus isolation}

As shown in Table 1, among 112 fish in 1999, 51 fish were aquabirnavirus-positive and two samples from Wakasa Bay were VHSV-positive. Although VHSVpositive samples were restricted in Wakasa Bay, birnaviruses were isolated from the samples caught in all coastal areas except Funka Bay and the prevalence was quite high (46\%). In the second year (2000) of the survey, 16 samples were VHSV-positive and 60 samples were aquabirnavirus-positive among 162 samples. In the second year, VHSV was detected not only from Wakasa Bay but also from Hakata Island area. The detection rate of birnavirus in 2000 (37\%) was almost equal to that of 1999 , while the rate of VHSV-positive samples in 2000 (9.9\%) was little higher than that of 1999 survey (1.8\%). Number of fish infected with both viruses was 2 and 5 in 1999 and 2000, respectively. Most of the VHSV-positive samples were collected in winter (December to February) or spring (March to May) when water temperature was comparatively low (Inland Sea: approximately $10-16^{\circ} \mathrm{C}$, Wakasa Bay: approximately $\left.7-10^{\circ} \mathrm{C}\right)$. VHSV was also detected from 4 fish in the summer (June) in Hakata Island when water temperature was about $18^{\circ} \mathrm{C}$. Throughout the survey, 89 out of 274 fish examined were diagnosed as anemic (Ht <20) and VHSV-positive and aquabirnavirus-positive samples were $4(4.5 \%)$ and $47(52.8 \%)$, respectively, among these anemic fish. No significant difference was observed in viral isolation rate between the head kidney and brain tissues (data not shown), and no correlation was observed between isolation rate and size of the fish (data not shown).

In the present study aquabirnaviruses were isolated using RTG-2 and/or SSN-1 cell lines and VHSV was isolated using FHM (with an anti-YTAV serum), EPC and/or SSN-1 cell lines. An unidentified virus was isolated using FHM and SSN-1 from one sample caught in Goto in 2000, from which aquabirnavirus was also isolated. To detect the coinfection of nodaviruses (causative agent of VNN) and other viruses, ten samples of the supernatant of the CPE-showing SSN-1 cells inoculated with brain homogenates were checked by IFAT using an antiserum against SJNNV, but no positive reaction was observed (data not shown).

\section{Virus identification}

Aquabirnavirus: The first isolate of aquabirnavirus, Obama \#10, was identified by the cross-neutralization test shown in Table 2. The result revealed that Obama \#10 is strongly related to YTAV and also there are weak cross-reactions between the Obama \#10 and IPNV strains (VR299, Ab and Sp). The antigenic relatedness was analyzed by the method described by Hill and Way (1995) as shown in Table 3. The value $r^{*}(=1 / r)$ shows 
Table 2. The result of the cross-neutralization between the three representative IPNV strains, YTAV and a new isolate Obama \#10

\begin{tabular}{|c|c|c|c|c|c|c|}
\hline \multirow{3}{*}{ Virus } & \multirow{3}{*}{$\begin{array}{c}\text { Titre } \\
\left(\mathrm{TCID}_{50} / \text { well }\right)\end{array}$} & \multicolumn{5}{|c|}{ Antiserum } \\
\hline & & \multicolumn{3}{|c|}{ IPNV- } & \multirow{2}{*}{ YTAV } & \multirow{2}{*}{ Obama \#10 } \\
\hline & & VR299 & $A b$ & $\mathrm{Sp}$ & & \\
\hline IPNV-VR299 & 2.5 & $>5120^{* 1}$ & $<40$ & 80 & 640 & 640 \\
\hline IPNV-Ab & 1.75 & 320 & 5120 & $<40$ & 2560 & 160 \\
\hline IPNV-Sp & 1.5 & 80 & $<40$ & 1280 & 160 & 80 \\
\hline YTAV*2 & 2.0 & 640 & 40 & 40 & 20480 & 2560 \\
\hline YTAV*3 & 3.0 & 320 & $<40$ & $<40$ & 10240 & 1280 \\
\hline Obama \#10 & 2.0 & 1280 & 80 & 40 & 40960 & 5120 \\
\hline
\end{tabular}

*1: Maximum dilution of antiserum to neutralize.

*2. isolated from yellowtail.

*3: isolated from Japanese flounder.

Table 3. Antigenic relationship represented by $r^{*}$ value between the three representative IPNV strains, YTAV and a new isolate Obama \#10

\begin{tabular}{lccccc}
\hline \multirow{5}{*}{ Virus } & \multicolumn{5}{c}{$r^{*}$} \\
\cline { 2 - 5 } & $\begin{array}{l}\text { IPNV- } \\
\text { VR299 }\end{array}$ & IPNV-Ab & IPNV-Sp & YTAV & Obama \#10 \\
\hline IPNV-VR299 & 1.0 & $>45.3$ & $>32.0$ & $>16.0$ & $>5.7$ \\
IPNV-Ab & 1.0 & $>64.0$ & 32.0 & 45.3 \\
IPNV-Sp & & 1.0 & 64.0 & 45.3 \\
YTAV & & & 1.0 & 1.0 \\
Obama \#10 & & & 1.0 \\
\hline$r^{*}=\sqrt{\left(r^{1} \times r^{2}\right)}$ & $r^{1}=$ (homologous titre virus1) / (hetelogous titre virus2) \\
$r^{2}=$ (homologous titre virus2) / (hetelogous titre virus1)
\end{tabular}

the extent of antigenic similarity between two virus isolates in a reciprocal cross-neutralization test. As shown in Table 3, Obama \#10 isolate was identical to YTAV with $r^{\star}$ value of 1 . On the other hand, the new isolate was distinct from both of IPNV-Ab and Sp strains with $r^{*}$ value of $>20$.

The remaining virus isolates showing aquabirnaviruslike CPE were determined by the reductions of viral titre at $10^{2}-10^{5} \mathrm{TCID}_{50}$ in the qualitative neutralization test as aquabirnavirus except for one isolate (the unidentified virus) as mentioned above. The one isolate, which was not neutralized with the antiserum against YTAV, also did not show any reaction with antisera against YTAV, VHSV, SJNNV or HIRRV in IFAT test.

The purified virion of Obama \#10 was revealed by electron microscopy to be an aquabirnavirus, being nonenveloped, icosahedral and approximately $70 \mathrm{~nm}$ in diameter (Fig. 2).

VHSV: The first two isolates (Obama \#25 and \#26) were determined as VHSV by serological, genetical and structural protein analyses in the previous paper (Takano et al., 2000). The remaining isolates were also identified as VHSV by IFAT using MAb to VHSV N protein. Granular positive stainings were observed primarily around the peripheral part of the cytoplasm in the

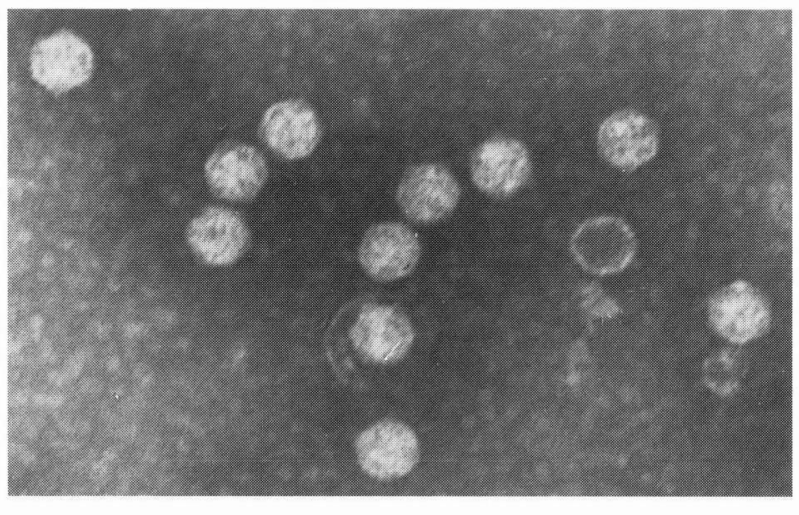

$\overline{100 \mathrm{~nm}}$

Fig. 2. Electron micrograph of negatively stained virions of an aquabirnavirus isolate, Obama \#10.

majority of infected cells. Any positive stainings were not observed in the cells inoculated with IHNV, HIRRV or aquabirnavirus as negative control.

Pathogenicity of the isolates

Aquabirnavirus: During the experiment, no mortality or abnormal condition including anemia was observed in flounder injected with the 4 aquabirnavirus isolates 


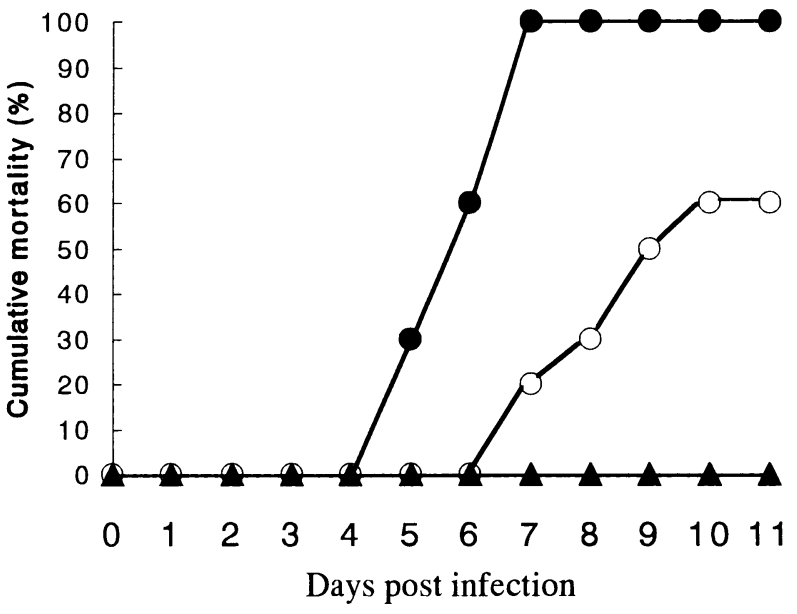

Fig. 3. Cumulative mortality of young Japanese flounders challenged with VHSV isolate Obama \#25 by i.m. injection. : $10^{6.0} \mathrm{TCID}_{50} /$ fish, $\bigcirc: 10^{2.0} \mathrm{TCID}_{50} /$ fish, $\Delta$ : MEM10 (control).

(Obama \#10, Obama \#29, Izu \#3, Izu \#20) even at higher doses.

VHSV: The Obama \#25 displayed strong virulence against Japanese flounder in the present challenge test. The mortality commenced on 4-th day post inoculation in the $10^{6.0} \mathrm{TCID}_{50}$-injected group and reached $100 \%$ in 7 days (Fig. 3). In the low dose group $\left(10^{2.0}\right.$ $\mathrm{TCID}_{50} / \mathrm{fish}$ ), $60 \%$ of fish died until the end of the experiment. No mortality was recorded in the control group throughout the experiment. Affected fish showed some behavioral changes including anorexia, lethargic swimming and gasping respiration. Moribund flounder showed gross clinical signs similar to those of VHSV infection in flatfish (Smail, 1999). Most common external signs were dark coloration of the body with hemorrhagic fins and abdominal swelling, and the internal signs included ascites and extensive hemorrhage in the muscle and/or viscera. The virus with titres higher than $10^{7.8} \mathrm{TCID}_{50} / \mathrm{g}$ was recovered from the tissues of brain, heart and head kidney of all examined 4 moribund fish and 2 survivors in the $10^{2.0} \mathrm{TCID}_{50}$-injected group.

\section{Discussion}

In the present study, the prevalence of aquabirnavirus in wild Japanese flounder was quite high, 46\% and $37 \%$ in the 1999 and 2000 surveys, respectively. A number of reports have described the isolation of aquabirnavirus from marine and freshwater fish in the world (Reno, 1999). Recently, the isolations of aquabirnaviruses were reported from several wild flatfishes, such as plaice Pleuronectes platessa, dab Limanda limanda and flounder Platichthys flesus in the North Sea, the Skagerrak or the Kattegat (Skall et al., 2000), and flounder Rhombosolea tapirina in Australia (Crane et al.,
2000). No clinical changes were observed among these infected fish, therefore it was suggested that these fish are potential carriers of the virus. Comparing with those foreign data, the detection rate of aquabirnavirus in Japanese flounder seems much higher than those of freshwater fishes (Bucke et al., 1979) but not so different from those of marine fishes, especially flatfishes (Skall et al., 2000).

The representative isolate of aquabirnavirus in this study, Obama \#10, was identified as YTAV by crossneutralization tests. It was also neutralized by antisera against the three prototypes (VR-299, Ab and Sp) of IPNV although there are antigenically distances from them, similar to the past isolates of YTAV (Kusuda et al., 1993; Nakajima and Sorimachi, 1994; Hosono et al., 1994). In this study, the reduction of titre in the qualitative neutralization test ranged from $10^{2}$ to $10^{5}$ among the isolates. Also in the viral structure protein analyses by SDS-PAGE, two patterns of VP2 mobility were observed among the present aquabirnavirus isolates (data not shown). These results may indicate that the aquabirnaviruses isolated from wild Japanese flounder populations can be divided into two or more serological types.

It is known that YTAV causes severe disease condition in juvenile of cultured yellowtail (Sorimachi and Hara, 1985) and flounder (2.4 g) (Kusuda et al., 1989), but the present isolates induced no mortality in the challenged young flounder $(9.7 \mathrm{~cm}, 8.7 \mathrm{~g})$ even with a high dose $\left(10^{7.6} \mathrm{TCID}_{50} / \mathrm{fish}\right)$. It is not clear whether even low virulent strains of YTAV like the present isolates can cause disease in compromised fish, or mortalities are caused in cultured fish by exceptionally high virulent strains. Comparative studies on the virulence of YTAV isolates should be made using flounder of different developmental stages between the present isolates and those isolated from diseased flounder.

Besides aquabirnavirus, VHSV was isolated from samples collected in the Wakasa Bay and Hakata Island. The detection rate was 6.6\% (18/274) and the virus was isolated mostly from the samples collected in spring or winter when water temperatures were lower than $16^{\circ} \mathrm{C}$. Around the North Sea and Baltic Sea, the detection rate of VHSV from wild fish species was $3.4 \%$ (Mortensen et al., 1999), whereas VHSV was isolated from wild Pacific herring in Prince William Sound, Alaska, USA at the rate of $4.7 \%$ (Marty et al., 1998). Stone et al. (1997) suggested that all marine fish species are potential carriers of the VHSV. Thus, the distribution of VHSV in other marine fishes should be investigated in the coastal areas of Japan.

In the transmission trial, high mortalities resulted from the inoculation $\left(10^{2.0}\right.$ and $\left.10^{6.0} \mathrm{TCID}_{50} / \mathrm{fish}\right)$ of the virus in young flounder $(13.8 \mathrm{~cm}, 24.8 \mathrm{~g})$ in a short period. This result indicates that VHSV would be a serious threat to released young flounder as well as wild 
ones in the sea. Mass mortalities due to a new viral disease in cultured flounder have been observed in the Inland-Sea of Japan since $1996^{* 1 * 2}$, and recently, the causative virus was identified as VHSV (Isshiki et al., 2001). It is not made clear that VHSV had entered into culture farms from wild flounder populations by horizontal transmission or the virus was transferred in hatcheries by vertical transmission from wild spawners to their offsprings.

As mentioned first, not a small number of wild flounder showing severe anemia have been observed in Japanese coastal area since 1996. To detect the virus associated with this disease condition was one aim of the present study. Although there was a slight difference in detection rate of aquabirnavirus between anemic fish (53\%) and non-anemic fish (35\%), the aquabirnavirus detected does not seem to be the causative agent of the anemia. Because any isolate did not induce anemia in the challenged fish during the pathogenicity experiment. Also, the fact that not all anemic fish were infected with aquabirnavirus indicates that this virus is not the primary agent of the anemia. There was also no correlation between the presence of VHSV and anemic disease condition in flounder. Therefore the causative virus of the anemia, if any, was not isolated in this study. Recently it is considered that the monogenean parasite Neoheterobothrium hirame sp. nov. (Ogawa, 1999) is responsible for this disease (Yoshinaga et al., 2000).

\section{Acknowledgements}

We wish to thank Drs. M. Yoshimizu, H. Fukuda, M. Sorimachi and N.J. Olesen for providing antisera against IHNV and VHSV used in this study. We are also thankful to staffs of each Station of JASFA for providing fish for this study. This study was partly supported by a grant from the Ministry of Education, Science, Sport and Culture of Japan (Grant-in-aid for Scientific Research (C), grant number: 12660172).

\section{References}

Bucke, D., J. Finlay, D. McGregor and C. Seagrave (1979): Infectious pancreatic necrosis (IPN) virus: its occurrence in

\footnotetext{
*1 Nagano, T., T. Isshiki and K. Miki (1997): A study on mass mortalities observed among cultured Japanese flounder in Kagawa Prefecture -I. Epidemiology and pathological examinations. In "Program and abstracts of the spring meeting of the Japanese Society of Fish Pathology in 1997". 12 p. (In Japanese)

*2 Isshiki, T. and T. Nagano (1997): A study on mass mortalities observed among cultured Japanese flounder in Kagawa Prefecture -II. Pathogenicity and characterization of the isolated virus. In "Program and abstracts of the spring meeting of the Japanese Society of Fish Pathology in 1997". $12 \mathrm{p}$. (In Japanese)
}

captive and wild fish in England and Wales. J. Fish Dis., 2, 549-553.

Crane, M. St. J., P. Hardy-Smith, L. M. Williams, A. D. Hyatt, L. M. Eaton, A. Gould, J. Handlinger, J. Kattenbelt and N. Gudkovs (2000): First isolation of an aquatic birnavirus from farmed and wild fish species in Australia. Dis. Aquat. Org., 43, 1-14.

Frerichs, G.N., H.D. Rodger and Z. Peric (1996): Cell culture isolation of piscine neuropathy nodavirus from juvenile sea bass, Dicentrarchus labrax. J. Gen. Virol., 77, 2067-2071.

Hill, B. J. and K. Way (1995): Serological classification of infectious pancreatic necrosis (IPN) virus and other aquatic birnaviruses. Ann. Rev. Fish Dis., 5, 55-77.

Hosono, N., S. Suzuki and R. Kusuda (1994): Evidence for relatedness of Japanese isolates of birnaviruses from marine fish to IPNV. J. Fish Dis., 17, 433-437.

lida, Y., K. Masumura, T. Nakai, M. Sorimachi and H. Matsuda (1989): A viral disease in larvae and juveniles of the Japanese flounder Paralichthys olivaceus. J. Aquat. Anim. Health, 1, 7-12.

Isshiki, T., K. Kawai and R. Kusuda (1989): Incidence of yellowtail ascites virus (YAV) in wild yellowtail fingering. Nippon Suisan Gakkaishi, 55, 633-637. (In Japanese with English abstract)

Isshiki, T., T. Nishizawa, T. Kobayashi, T. Nagano and T. Miyazaki (2001): An outbreak of VHSV (Viral Hemorrhagic Septicemia Virus) infection in farmed Japanese flounder Paralichthys olivaceus in Japan. Dis. Aquat. Org., In press.

Kimura, T., M. Yoshimizu and S. Gorie (1986): A new rhabdovirus isolated in Japan from cultured hirame (Japanese flounder, Paralichthys olivaceus) and ayu (Plecoglossus altivelis). Dis. Aquat. Org., 1, 209-217.

Kusuda, R., K. Kado, Y. Takeuchi and K. Kawai (1989): Characteristics of two virus strains isolated from young Japanese flounder Paralichthys olivaceus. Suisanzoshoku, 37, 115120. (In Japanese with English abstract)

Kusuda, R., Y. Nishi, N. Hosono and S. Suzuki (1993): Serological comparison of birnaviruses isolated from several species of marine fish in south west Japan. Fish. Pathol., 28, 91-92.

Leong, J. C., D. Brown, P. Dobos, F. S. B. Kibenge, J. E. Ludert, H. Muller, E. Mundt and B. Nicholson (2000): Family Birnaviridae. In "Virus taxonomy-seventh report of the international committee on taxonomy of viruses" (ed. by M. H. V. van Regenmortel et al.). Academic Press, California, pp. 481-490.

Lorenzen, N., N. J. Olesen and P. E. Vestergård-Jørgensen (1988): Production and characterization of monoclonal antibodies to four egtved virus structural proteins. Dis. Aquat. Org., 4, 35-42.

Marty, G. D., E. F. Freiberg, T. R. Meyers, J. Wilcock, T. B. Farver and D. E. Hinton (1998): Viral hemorrhagic speticemia virus, Ichthyophonus hoferi, and other causes of morbidity in Pacific herring Clupea pallasi, spawning in Prince William Sound, Alaska, USA. Dis. Aquat. Org., 32, $15-40$.

Matsuoka, M., K. Inouye and K. Nakajima (1996): Cultured fish species affected by red sea bream iridoviral disease from 1991 to 1995. Fish Pathol., 31, 233-234. (In Japanese with English abstract)

Miwa, S. and K. Inouye (1999): Histopathological study of the flounder with anemia found in various places in Japanese coastal water. Fish Pathol., 34, 113-119. (In Japanese with English abstract)

Mortensen, H. F., O. E. Heuer, N. Lorenzen, L. Otte and N. J. Olesen (1999): Isolation of viral haemorrhagic septicaemia 
virus (VHSV) from wild marine fish species in the Baltic Sea, Kattegat, Skagerrak and North Sea. Virus Res., 63, 95-106.

Muroga, K. (1995): Viral and bacterial diseases in larval and juvenile marine fish and shellfish: a review. Fish Pathol., 30, 71-85. (In Japanese with English abstract)

Muroga, K. (2000): Notes on the seed production in sea-farming program with reference to disease control. Saibai Giken, 28, 39-45. (In Japanese)

Muroga, K. (2001): Viral and bacterial diseases of marine fish and shellfish in Japanese hatcheries. Aquaculture (In press).

Muroga, K., T. Furusawa and I. Furusawa (1998): A review: viral nervous necrosis in striped jack, Pseudocaranx dentex. Suisanzoshoku, 46, 473-480. (In Japanese with English abstract)

Mushiake, K., T. Nishizawa, T, Nakai, I. Furusawa and K. Muroga (1994): Control of VNN in striped jack: Selection of spawners based on the detection of SJNNV gene by polymerase chain reaction (PCR). Fish Pathol., 29, 177-182.

Nakajima, K. and M. Sorimachi (1994): Serological and biochemical characterization of two birnaviruses; VDV and YAV isolated from cultured yellowtail. Fish Pathol., 29, 183-186.

Nguyen, H. D., T. Mekuchi, K. Imura, T. Nakai, T. Nishizawa and K. Muroga (1994): Occurrence of viral nervous necrosis (VNN) in hatchery-reared juvenile Japanese flounder Paralichthys olivaceus. Fisheries Sci., 60, 551-554.

Ogawa, K. (1999): Neoheterobothrium hirame sp. nov. (Monogenea: Diclidophoridae) from the buccal cavity wall of Japanese flounder Paralichthys olivaceus. Fish Pathol., 34, 195-201.

Olesen N. J. and N. Lorenzen (1999): Production of neutralizing antisera against viral hemorrhagic septicemia (VHS) virus by intravenous injection of rabbits. J. Aquat. Anim. Health, 11. 10-16.

Reno, P. W. (1999): Infectious pancreatic necrosis and associ- ated aquatic birnaviruses. In "Fish diseases and disorders Vol.3. Viral, bacterial and fungal infection" (ed. by P. T. K. Woo and D. W. Bruno). CABI Publishing, New York, pp. 155.

Skall (nee Mortensen), H. F., S. Mellergaard and N. J. Olesen (2000): Isolation of birnavirus serogroup B in wild and aquacultured fish species. Bull. Eur. Ass. Fish Pathol., 20, 229-236.

Smail, D. A. (1999): Viral haemorrhagic septicaemia. In "Fish diseases and disorders Vol.3. Viral, bacterial and fungal infections" (ed. by P. T. K. Woo and D. W. Bruno). CABI Publishing, New York, pp. 123-147.

Sorimachi, M. and T. Hara (1985): Characteristics and pathogenicity of a virus isolated from yellowtail fingerlings showing ascites. Fish Pathol., 19, 231-238. (In Japanese with English abstract)

Stone, D.M., K. Way and P.F. Dixon (1997): Nucleotide sequence of the glycoprotein gene of viral haemorrhagic sepicaemia (VHS) viruses from different geographica areas: a link between VHS in farmed fish species and viral isolated from North Sea cod (Gadus morhua L.). J. Gen. Virol. 78, 1319-1326.

Takano R., T. Nishizawa, M. Arimoto and K. Muroga (2000): Isolation of viral haemorrhagic septicaemia virus (VHSV) from wild Japanese flounder, Paralichthys olivaceus. Bull. Eur. Ass. Fish Pathol., 20, 186-193.

Tanaka, M., M. Yoshimizu, M. Kusakari and T. Kimura (1984): Lymphocystis disease in kurosoi Sebastes schlegeli and hirame Paralichthys olivaceus in Hokkaido, Japan. Bull. Japan. Soc. Sci. Fish., 50, 37-42. (In Japanese with English abstract)

Yoshinaga, T., T. Kamaishi, I. Segawa, A. Kumagai, C. Nakayasu, K. Yamano, T. Takeuchi and M. Sorimachi (2000): Hematology, histopathology and the monogenean Neoheterobothrium hirame infection in anemic flounder. Fish Pathol., 35, 131-136. 